\title{
Théodore Herpin:
}

\section{Neglected Contributions in the} Understanding of Epilepsy

\author{
J.M.S. Pearce \\ Emeritus Consultant Neurologist, Department of Neurology, Hull Royal Infirmary, Hull, UK
}

\section{Key Words}

Herpin, Théodore $\cdot$ Juvenile myoclonic epilepsy •

Des accès incomplets

\begin{abstract}
In contrast to earlier notions of epilepsy, Théodore Herpin considered that when symptoms started in the periphery or the viscera their origin was in the brain, a view later lauded by Hughlings Jackson. His respected book Des accès incomplets did not attempt to deal with disordered physiology but was designed to help physicians to recognise and treat epilepsy early in its course. He described juvenile myoclonic epilepsy and vividly and accurately portrayed many other clinical phenomena of epilepsy.
\end{abstract}

Copyright $\odot 2005$ S. Karger AG, Basel

At the dawn of the 19th century, the nature of the epileptic phenomena, its physiological basis and anatomical location were clouded in mysticism and ignorance. Theories had included excess phlegm in the brain and, according to Paracelsus, a boiling up of the vital spirits ('spiritus animalis') in the brain. In the 17th century, Willis visualised an 'explosion of the animal spirits in the centre of the brain'. A century later, Marshall Hall talked of abnor- mal irritability in the afferent limb or central section of the reflex arc. However he located the primary source as in the cervical cord, loss of consciousness in a fit being the result of secondary cerebral venous congestion. Brown-Séquard ascribed an important role to peripheral afferent nerve irritability and believed that the medulla oblongata was the central component of the reflex mechanism. Todd and Jackson in the mid 19th century started to study and elucidate the diverse phenomena that characterise epilepsy. But Théodore Herpin (1799-1865) made early and fundamental contributions that have been undervalued or overlooked. When remembered, it is his account of juvenile myoclonic epilepsy that is usually recalled; however, his other contributions were farreaching.

Juvenile myoclonic epilepsy was first reported by Herpin in 1867 when he described a bright boy aged 13 years who developed upper body jerks that progressed to 'full seizures' 3 months later [1]. Rabot, Lundborg and others reported similar seizures and used the term 'impulsions' to describe the myoclonic jerks. Its delineation was unsatisfactory for 80 years until Janz and colleagues in Germany reported 47 cases and at first named it impulsive petit mal' [2, 3]. Lund in 1975 and later Janz [4] referred to 'juvenile myoclonic epilepsy', and it became known as the Janz syndrome [5]. Juvenile myoclonic epilepsy [6] is characterised by sudden, often repeated, single, symmet-

\section{KARGER \\ Fax +41613061234 E-Mail karger@karger.ch} www.karger.com
(C) 2005 S. Karger AG, Basel 0014-3022/05/0543-0135\$22.00/0

Accessible online at: www.karger.com/ene
J.M.S. Pearce

304 Beverley Road

Anlaby, East Yorks HU10 7BG (UK) 
rical and synchronous jerks of the arms and less often the legs in the first hour after waking [7]. Attacks usually begin in adolescence. Consciousness is unimpaired. The ictal EEG shows 4- to 6-Hz multispike and wave complex; the interictal record may be normal.

Most sufferers develop later generalised fits, and 20$30 \%$ of patients have a history of preceding absence attacks. Often familial, it is suppressed by valproate, with a high recurrence rate when treatment is stopped. Recent work indicates a region associated with juvenile myoclonic epilepsy on chromosome 6p12-p11 (EJM1) and a new gene (EFHC1) linked to the HLA gene. However, major genes account for relatively few cases, and heterogeneous, multifactorial inheritance probably obtains in many patients.

\section{Théodore Herpin (1799-1865)}

Herpin was born in Lyon, France. He graduated in Medicine from the Universities of Paris and Geneva in 1822, practising in Geneva for 30 years, and then in Paris. A little of his life history is available in Auguste Voisin's preface to Des accès incomplets, and there has been another more recent short account of his career [8], providing a photograph of Herpin, but little additional biography. In addition to describing juvenile myoclonic epilepsy, he made other significant contributions to epilepsy preceding Hughlings Jackson (1835-1911). He wrote two books, Du pronostic et du traitement curatif de l'épilepsie [9] and Des accès incomplets d'épilepsie, published posthumously in 1867 [10]. His accounts were based not on institutionalised patients, but on epilepsy in consulting practice.

\section{Epilepsy May Be Curable if Treated Early}

His thesis of 1850 was submitted to the Paris Faculty of Medicine and later published in 1852 as Du pronostic et du traitement curatif de l'épilepsie. It concluded that, contrary to the general view, epilepsy was often curable, particularly if treated appropriately soon after its onset. However, he used only zinc salts and later introduced zinc lactate for its treatment. This conviction that the longer epilepsy was left untreated, the smaller the chance of curing it has been justified in principle by subsequent experience, but it appears unduly optimistic in his own time because of the lack of effective anticonvulsants.
But this belief undoubtedly motivated his writing of Des accès incomplets to encourage readers to identify epilepsy in its different manifestations as early as possible. These 'incomplete attacks' he found in half of his 300 patients with epilepsy, but they included those with secondary generalised fits beginning with focal aurae (accès incomplets).

\section{Des accès incomplets, préludes and vertiges}

Herpin classified the onset of incomplete forms of epilepsy in his 300 patients with incomplete attacks into 'trois genres de débuts: périphériques, viscéraux, encéphaliques'. Other incomplete epilepsies of encephalic origin involved special sensory (visual, auditory) or perceptual experiences, including the peculiar dreamy states and feelings of unreality, which Kinnier Wilson called déjà vu. For instance, he related on page 21:

'In one of these two circumstances, the convulsion that followed was arrested in the hand; in the other, the attack was incomplete. Here therefore, while admitting a true dizziness, again we doubt, if it accompanies the cramp, as an isolated prelude, or beginning of an attack. As always therefore, the dizziness is not, in these cases, a symptom of the onset.'

Hughlings Jackson praises and quotes Herpin's book at length [11]: 'I wish to show', says Jackson, 'by the quotations from Herpin that statements essentially the same as those I make were made by a great authority long ago.' For example, Jackson cited (translated from Des accès incomplets, p. 140):

'Of three patients who began with false perceptions of smell, ... The third [patient] had sometimes simple preludes; the bad smells did not extend to the nasal fossae (while in vertigo the feeling went down into the throat); it was soon all finished; there was no trace of intellectual disorder; ...'

'De trois patients à début par de fausses perceptions d'odeur, ... Le troisième avait quelquefois de simples préludes; la mauvaise odeur ne s'étendait pas au-delà des fosses nasales (tandis que dans le vertige la sensation descendait dans la gorge); bientôt tout était fini; il n'y avait pas trace de trouble intellectuel; ...'

A peripheral onset comprised focal motor, Jacksonian seizures. The 'aura epileptica' occurred in this group and was one type of 'prelude'. Herpin also related a visceral onset with abdominal disturbances including the rising epigastric aura. In chapter IV, pp. 105-138, he described the epileptic cry, convulsions as well as visual aurae, hallucinations, head turning, epigastric sensations, repetitive utterances and a variety of intellectual and behavioural disorders as integral parts of attacks. The 'march' of symptoms is clearly depicted in several of his cases. His ence- 
phalic group also contained a peculiar variety of attack that began with momentary bilateral myoclonic jerks, which Herpin termed 'concussions' - a subgroup separate from the other epilepsies. This was probably the first account of juvenile myoclonic epilepsy ('impulsive petit mal'). In the concussive subgroup, he described (observation 23) a possible example of the Lennox-Gastaut syndrome.

Des accès incomplets used the words 'preludes' and 'episodes' for attacks in which consciousness was preserved; they are now classified as epileptic aurae and partial seizures. Preludes were shorter and involved less disturbance of body function than his episodes. He used the term non-convulsive events or 'vertiges' for attacks in which consciousness was impaired or lost, but without generalized tonic-clonic convulsive seizure. This was a continental use of the word 'vertigo,' as distinct from the English word - referring to hallucinations of movement, often rotational. Herpin's epileptic 'vertiges' roughly correspond to the International League against Epilepsy's complex partial seizures, its absence seizures, and to some of its myoclonic seizures of generalized epilepsy. At the same time Trousseau used the term 'vertigo' in a different sense than we use it today [12]; he equated it with petit mal, fits of unconscious laughter, a sense of astonishment or ecstasy, a variety of complex automatisms and absence attacks [13]. 'Petit mal' was used more widely to include any generalised non-convulsive event but was not restricted to absence attacks, as in modern practice (see Eadie [1]). Herpin did not specifically identify absence seizures (described in 1705 by Poupart and in 1770 by Tissot [14]) in his 300 patients. He also described the commoner generalised tonic-clonic convulsion.

Importantly, he emphasised that all epileptic seizures, whether complete or incomplete, began in the same way and, therefore, must originate in the same locus in the brain (translated from Des accès incomplets, p. 38; vide infra):

'The lesions indicated were able to play a role in the determination of the siege of the initial symptoms; they are able, while provoking a reflex action, to play a role as occasional causes of the attacks, but they are unable, by themselves, to have produced epilepsy and, in deciding treatment, they can't indicate the least means of palliation.

In general, we would invoke against the theory of sympathetic external epilepsy, in the same subject, the siege of the convulsion can from time to time be different from its habitual place. Thus the leg or the cheek can replace sometimes the arm; we see several examples in the observations that we will soon reproduce. Although it is rare in the same illness, this occurrence is observed in too many epileptics of this kind for it to be possible to admit that the point of origin of the aura [in arm or leg, for example] must be the source of the illness [in the brain] or the same as the morbid cause.
Nothing proves therefore that external, sympathetic epilepsies exist. Everything establishes, to the contrary, that these cases constitute but one symptomatic variety.'

'Les lésions indiquées pouvaient jouer un rôle dans la détermination du siège des symptômes initiaux; elles peuvent en mesure, tout en provoquant une action réflexe, jouer un rôle en tant que causes occasionnelles des attaques, mais elles ne peuvent pas, par elles-mêmes, avoir l'épilepsie produite et, en faisant le traitement, ils ne peuvent pas indiquer les moindres moyens de palliatif. En général, nous appellerions contre la théorie d'épilepsie externe sympathique, dans le même sujet, qui est que le siège de la convulsion peut du temps au temps être différent de son endroit habituel. Ainsi la jambe ou la joue peut remplacer parfois le bras; nous voyons plusieurs exemples dans les observations que nous reproduirons bientôt. Bien qu'il soit rare dans la même maladie, on observe cette occurrence dans trop d'éepileptiquees de cette sorte pour elle pour être possible pour admettre que le point d'origine de l'aura doit être, soit la source de maladie, ou identique àque lae cause. Rien ne prouve donc que les épilepsies externes et sympathiques existent. Tout établit, à l'effet contraire, que ces cas constituent mais une variété symptomatique.'

Early in the text of Des accès incomplets, Herpin suggests two principles:

(1) in a patient with epilepsy, all seizures began in the same way, although the further development of the seizures might vary;

(2) intermittent minor paroxysmal events were merely incomplete versions of the same person's more major events.

He therefore believed that in the individual, all attacks must start in the same place in the brain.

\section{Site of Origin of the Epileptic Discharge}

At the time of Herpin's studies, the site of origin of epilepsy was much disputed [15]. Jacobus Schroeder van der Kolk (1797-1862) [16], Professor of Anatomy and Physiology at Utrecht in 1826, had performed autopsies and used an early microscope to study the brains of epileptics. His conclusions were given in the Sydenham Lecture of 1859 , 'On the minute structure and functions of the medulla oblongata and the proximate causes and rational treatment of epilepsy'. Van der Kolk found 'dilatation of the veins which appeared filled with blood in the cortex, medulla and spinal cord'. The medulla 'showed a fatty degeneration with albuminous intracellular fluid'. Those who bit their tongues during a fit had dilated vessels feeding the hypoglossal nucleus whereas those without a bitten tongue had dilated vessels of the vagal nucleus.

'The first cause of epilepsy ... is exalted sensibility and excitability of the medulla oblongata ... These caused the medulla to be "liable to discharge upon itself" and these discharges caused spasms 
in blood vessels leading to hyperaemia followed by "involuntary reflex movements"... Frequent or repeated fits caused inflammation of the cortex leading to "incurable dementia" due to "thickening and dilatation of blood vessels", [17].

\section{Robert Bentley Todd [18] believed that}

'in all instances the hemispheric lobes are first disturbed, next follow the corpora quadrigemina, and upon the intensity of the disturbance depends the extent to which the medulla oblongata and the spinal cord are engaged' [19].

Brown-Séquard's theory was of peripheral, centripetal initiation of epileptogenesis [20], Nothnagel had referred to 'the convulsive centre' adjacent to the centre for respiration. Hammond cited van der Kolk in his $A$ Treatise on the Diseases of the Nervous System (1871). Hammond thought that the seat of epilepsy lay in the medulla and that the demonstrated lesions in the cortex of certain epileptics excited the medulla to produce the convulsive fit.

After Herpin and Jackson, Gowers' writing was a fair summary of the prevalent ambivalence, but he clearly favoured the cortex as the essential source of epilepsy:

'On the other hand, of all the regional diseases of the brain, lesions of the convolutions stand incomparably first as a cause of convulsions, ... The conclusion, then, is that all the phenomena of the fits of idiopathic epilepsy may be explained by the discharge of gray matter ...' [21].

In contrast to earlier ideas, Herpin considered that when symptoms started in the periphery or the viscera (les épilepsies externes et sympathiques) their origin was in the brain, but he failed to infer, as Jackson did, that this implied a localization of function within the cerebral cortex. It was Hughlings Jackson (1834-1911) who finally formulated a physiological and rational definition:

'A convulsion is but a symptom, and implies only that there is an occasional, an excessive, and a disorderly discharge of nerve tissue on muscles' [22].

Early in the text of Des accès incomplets, Herpin stated that he would not attempt to deal with disordered physiology but would help physicians to recognize and treat epilepsy early in its course. His portrayal of the clinical phenomena of epilepsy was extensive. But Jackson went further. He provided similarly detailed observations and carefully interpreted them in a framework of Spencerian philosophy and psychology as well as in his own original views of the hierarchical evolution of cerebral functions. Unhappily, Herpin died before Des accès incomplets was published. Thus, his book was less well known than it deserved and escaped Jackson's attention for some time.
Eadie regards Herpin's Des accès incomplets as 'one of the great landmarks in the unfolding of knowledge concerning the phenomena of epilepsy'. He asks what might have happened had Jackson read Des accès incomplets when it was first printed, instead of some 30 years later.

Jackson would have found confirmation of his own opinions. Herpin's autopsy findings showed a focal cortical lesion in one case of epilepsy of incomplete peripheral onset, which would have strengthened Jackson's belief that this type of epilepsy arose from a focal cortical lesion. Jackson might also have acknowledged the nature of Herpin's 'vertiges', before he had explored the significance of the 'dreamy state'.

Unfortunately, Herpin failed to extend his observations to indicate, as Hughlings Jackson did, that there was localization of function in the brain. Jackson confirmed similar phenomena and in 1899, late in his career, largely agreed with and extolled Herpin's deductions:

'I take this opportunity of advising the younger medical neurologist to study carefully Herpin's writing on Epilepsy. I have long known his valuable work, Du pronostic et du traitement curatif de l'épilepsie, 1852, but I have only recently heard of his still more valuable work, Des accès incomplets d'épilepsie, 1867. I give from the latter work a quotation which mentions one case of the association of an intellectual aura ("dreamy state") with a crude sensation warning of a smell in epileptic paroxysms ("third smell case")' [23].

\section{Conclusion}

Herpin's description of juvenile myoclonic epilepsy appears to be an original delineation of this syndrome. His wider observations on epilepsy and his interpretation of them preceded Hughlings Jackson's independent but similar concepts. Oswei Temkin in his authoritative monograph [24] remarks that:

'Herpin's observations were valid, regardless of any hypotheses. This cannot be said of Jackson, whose clinical observations directed him to anatomy, physiology and pathology, and then back to the bedside. The fact that he reasoned rather than dissected or experimented does not alter the essential scope of his work.'

In his epilogue he shows how Jackson's opinions were vindicated inter alia by Horsley and Macewan.

Eadie also points out that Jackson's more extensive, intellectual exploration of the implications of his observations made him a more important figure than Herpin in the history of epileptology. Nonetheless, Herpin was a figure of great significance, who shed new light on many clinical aspects of the epilepsies and recognised the importance of early diagnosis and treatment. 


\section{References}

$\checkmark 1$ Eadie MJ: The epileptology of Theodore Herpin (1799-1865). Epilepsia 2002;43:12561261.

2 Janz D, Matthes A: Die Propulsiv-Petit-malEpilepsie. New York, Karger, 1955.

3 Janz, D, Christian W: Impulsiv-Petit-mal. Dtsch Z Nervenheilkd 1957;176:346-386.

4 Janz D: Epilepsy with impulsive petit mal (juvenile myoclonic epilepsy). Acta Neurol Scand 1985;52:449-459.

$\checkmark 5$ Asconape J, Penry JK: Some clinical and EEG aspects of benign juvenile myoclonic epilepsy. Epilepsia 1984;25:108-114.

6 Schmitz B, Sander T (eds): Juvenile Myoclonic Epilepsy: The Janz Syndrome. Petersfield, Wrightson Biomedical, 2000.

7 Dreifuss FE: Juvenile myoclonic epilepsy: characteristics of primary generalized epilepsy. Epilepsia 1989;30:S1-S7.

$>8$ Schmidt D: Theodore Herpin - A mid-19th century view on epilepsy. Arch Neurol 1988; 45:1042-1044.

9 Herpin $\mathrm{T}$ : Du pronostic et du traitement curatif de l'épilepsie. Paris, thésis, 1852.

10 Herpin T: Des accès incomplets d'épilepsie. Paris, Baillière, 1867 (translation available in Schmidt, ref 10, document électronique, 1995, at http://visualiseur.bnf.fr/Visualiseur?Destination $=$ Gallica \&O=NUMM-76917).
11 Taylor J (ed): Selected Writings of John Hughlings Jackson. London, Staples Press, 1958, vol 1, pp 469-471.

12 Pearce JMS: Armand Trousseau. J Hist Neurosci 2002; 11:125-136.

13 Trousseau A in Lecture iii: on epilepsy; in Bazire PV (trans): Lectures on Clinical Medicine Delivered at the Hôtel-Dieu, Paris. London, New Sydenham Society, 1868, vol 1, pp 3398.

14 Tissot SA: Traité de l'épilepsie, faisant le tome troisième du traité des nerfs et de leurs maladies. Paris, Didot Le Jeune, 1770.

15 Pearce JMS: Early accounts of epilepsy; in Pearce JMS (ed): Fragments of Neurological History. London, Imperial College Press, 2003, pp 181-191.

16 Haas LF: Jacobus Ludovicus Shroeder van der Kolk (1797-1862). J Neurol Neurosurg Psychiatry 1994;57:1164.

17 Fine EJ, Fine D: JS van der Kolk's influence on American concepts of epilepsy. Proc 2nd Meet Int Soc Hist Neurosci, Leiden, 1997, p 29.

18 Pearce JMS: Robert Bentley Todd (18091860) and Todd's paralysis. J Neurol Neurosurg Psychiatry 1994;57:315.
19 Todd RB: On the pathology and treatment of convulsive diseases. London Med Gaz 1849; 8:822.

20 Brown-Séquard CE: Course of lectures on the physiology and pathology of the central nervous system delivered at the Royal College of Surgeons, England, in May 1858. Philadelphia, Collins printer, 1860, Lecture XI: On the etiology, nature and treatment of epilepsy, pp 178186.

21 Gowers WR: Epilepsy and Other Chronic Convulsive Diseases: Their Causes, Symptoms and Treatment. London, William Wood, 1885, pp 167-175.

22 Taylor J (ed): Selected Writings. London, Staples Press, 1931, vol 1, p 8.

23 Jackson JH, Purves Stewart J: Epileptic attacks with a warning of a crude sensation of smell and with the intellectual aura (dreamy state) in a patient who had symptoms pointing to gross organic disease of the right temporo-sphenoidal lobe. Brain, vol 22, 1899. Reprinted in Taylor J (ed): Selected Writings of John Hughlings Jackson. London, Staples Press, 1958, vol 1, pp 464-473.

24 Temkin O: The Falling Sickness. Baltimore, Johns Hopkins University Press, 1945, p 327. 